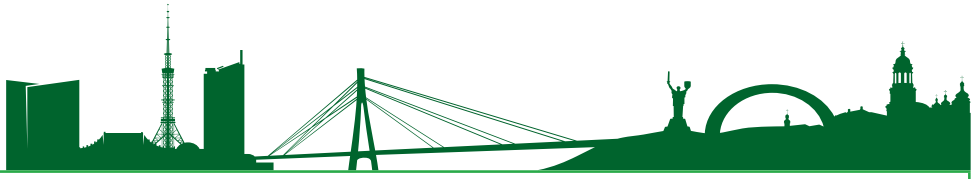

Doi: https://doi.org/10.33644/scienceandconstruction.v25i3.1

УДК 626.8 (075.8)

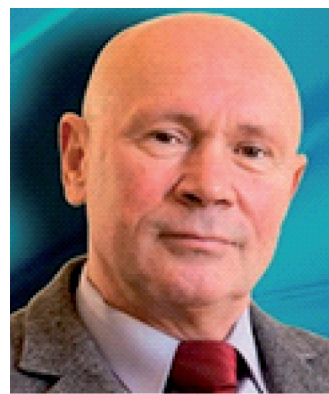

ФАРЕНЮК Г. Г.

Д-р техн. наук, професор, директор Державного підприємства "Державний науково-дослідний інститут будівельних конструкцій", м. Київ, Україна,

e-mail: farenyuk@ndibk.gov.ua тел. + 38 (044) 249-72-34

ORCID: 0000-0002-5703-3976

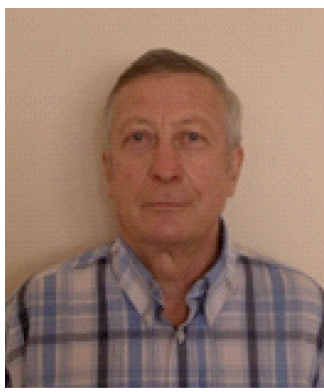

ШУМІнСБкИй В.Д.

Канд. техн. наук, провідний науковий співробітник Державного підприємства «Державний науководослідний інститут будівельних конструкцій», м. Київ, Україна, e-mail: shumikvd@gmail.com тел. +38 (096) 617-55-70 ORCID: 0000-0001-9270-6649

\title{
НАДІЙНІСТЬ ТА БЕЗПЕКА ГІДРОТЕХНІЧНИХ СПОРУД ДНІПРОВСЬКОГО ТА ДНІСТРОВСЬКОГО КАСКАДІВ ГЕС
}

\section{АНОТАЦІЯ}

В статті розглянута надійніть та безпека гідротехнічних споруд і стан нормативної бази в галузі гідротехнічного будівництва, що регламентує їх забезпечення. Гідротехнічні споруди - це відповідальні інженерні споруди, що широко застосовуються в різних сферах життедіяльності людини і галузях народного господарства. Тому важливою задачею гідроенергетики України є дотримання безпеки та надійністі роботи цих споруд. Наведено аналіз діючих в Україні нормативних документів, що регламентують вимоги до гідротехнічних споруд та підтримують їх надійність та безпеку. На даний час в Україні в галузі гідротехнічного будівництва діє низка застарілих нормативних документів (в тому числі строительные нормы и правила (СНиП) з часів СРСР) щодо проектування, будівництва та надійності і безпеки споруд, і в ряді випадків вони суперечать чинним в Україні правовим і нормативним документам. Наведені відмінності роботи та особливості експлуатації гідротехнічних споруд, що потребує їх врахування в нормативних документах. Це свідчить про необхідність невідкладного відновлення нормативної бази. Критерії безпеки і технічні стани гідротехнічних споруд, що знаходяться в експлуатації, є застарілими. Тому слід роз-

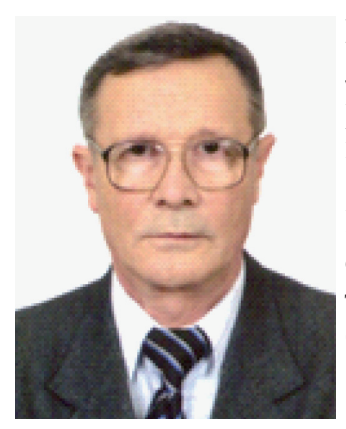

ВАЙНБЕРГ О.І.

Д-р техн. наук, заступник генерального директора приватного акціонерного товариства «Укргідропроект», м. Харків, Україна, e-mail: vaynberg@uhp.kharkov.ua тел. +38 (067) 573-48-08 ORCID: 0000-0002-9858-0001 робити нормативний акт на основі спеціальних досліджень, що регламентує підходи до визначення критеріїв безпеки, надійності та технічних станів гідротехнічних споруд, які знаходяться в тривалій експлуатації. Слід розробити «Технічний регламент гідротехнічних споруд», який врахує відмінності (особливості) умов їх роботи від інших споруд та особливості. Для правового регулювання діяльності із дотримання надійності та безпеки необхідно якнайшвидше завершити розробку проекту та прийняти Закон України «Про безпеку гідротехнічних споруд».

КАЮЧОВІ СЛОВА: безпека, надійність, гідротехнічні споруди, гідротехнічне будівництво, гідроелектростанція (ГЕС), гідроакумулююча електростанція (ГАЕС), нормативна база, державні та галузеві будівельні норми (ДБН, ГБН), стандарти України (ДСТУ)

\section{НАДЕЖНОСТЬ И БЕЗОПАСНОСТЬ ГИДРОТЕХНИЧЕСКИХ СООРУЖЕНИЙ ДНЕПРОВСКОГО И ДНЕСТРОВСКОГО КАСКАДОВ ГЭС}

\section{АННОТАЦИЯ}

В статье рассмотрена надежность и безопасность гидротехнических сооружений и состояние норма- 


\section{und 1 Nom}

тивной базы в области гидротехнического строительства, регламентирующие их обеспечение. Гидротехнические сооружения - это ответственные инженерные сооружения, широко применяемые в различных сферах жизнедеятельности человека и отраслях народного хозяйства. Поэтому важной задачей гидроэнергетики Украины является обеспечение безопасности и надежности работы этих сооружений. Приведен анализ действующих в Украине нормативных документов, регламентирующих требования к гидротехническим сооружениям, и обеспечивающих их надежность и безопасность. В настоящее время в Украине в области гидротехнического строительства действует ряд устаревших нормативных документов (в том числе строительные нормы и правила (СНиП) со времен СССР) по проектированию, строительству, надежности и безопасности сооружений и в ряде случаев они противоречат действующим в Украине правовым и нормативным документам. Приведены отличия работы и особенности эксплуатации гидротехнических сооружений, что требует их учета в нормативных документах. Это свидетельствует о необходимости безотлагательного восстановления нормативной базы по проектированию, строительству и эксплуатации этих сооружений, их надежности и безопасности. Критерии безопасности и технические состояния в отношении гидротехнических сооружений, находящихся в эксплуатации, являются устаревшими. Поэтому следует разработать нормативный акт на основе специальных исследований, регламентирующий подходы к определению критериев безопасности, надежности и технических состояний гидротехнических сооружений, находящихся в длительной эксплуатации. Следует разработать «Технический регламент гидротехнических сооружений», который учтет отличия в условиях их работы от других сооружений и особенности. Для правового регулирования деятельности по обеспечению надежности и безопасности необходимо как можно быстрее завершить разработку проекта и принять Закон Украины «О безопасности гидротехнических сооружений».

КЛЮЧЕВЫЕ СЛОВА: безопасность, надежность, гидротехнические сооружения, гидротехническое строительство, гидроэлектростанция, гидроаккумулирующая электростанция, нормативная база, государственные и отраслевые строительные нормы, стандарты Украины

RELIABILITY AND SAFETY OF HYDRAULIC STRUCTURES OF THE DNIEPER AND DNIESTER CASCADES OF HPP

\section{ABSTRACT}

The article considers the reliability and safety of hydraulic structures and the state of the regulatory framework in the field of hydraulic construction, regulating their provision. Hydraulic structures are responsible engineering structures that are widely used in various spheres of human activity and branches of the national economy. Therefore, an important task of the Ukrainian hydropower industry is to ensure the safety and reliability of these structures. The analysis of the current regulatory documents in Ukraine that regulate the requirements for hydraulic structures and ensure their reliability and safety is given. Currently, in Ukraine in the field of hydraulic engineering, there is a number of outdated regulatory documents (including construction norms and rules ( $\mathrm{SNiP}$ ) from the time of the USSR) on the design, construction and reliability and safety of structures, and in some cases they contradict the current legal and regulatory documents of Ukraine. The differences in behaviour and operation of hydraulic structures are covered and this is what should be considered in regulatory documents. This indicates the urgent need to restore the regulatory framework for the design, construction and operation of hydraulic structures, their reliability and safety. The safety criteria and technical conditions for hydraulic structures in operation are outdated. Therefore, it is necessary to develop a regulatory act based on special research that regulates approaches to determining the criteria for safety, reliability and technical conditions of hydraulic structures that are in long-term operation. It is necessary to develop a "Technical regulation of hydraulic structures", which will take into account the differences (features) of working conditions of hydraulic structures from other structures and their features. For legal regulation of activities to ensure the reliability and safety of hydraulic structures, it is necessary to complete the project development as soon as possible and to adopt the Law of Ukraine "On the safety of hydraulic structures".

KEYWORDS: safety, reliability, hydraulic structures, hydrotechnical structures, hydroelectric power station( HPP), accumulating power plant (APP), regulatory framework, state and sector construction standards (DBN, GBN), standards of Ukraine (DSTU)

\section{ВСТУП}

На сьогодні в світі використовується лише $16 \%$ енергетичного потенціалу річок (Парагвай використовує $100 \%$, Норвегія - 98 \%, Україна - до 10 \%. Бразилія, Канада, Нова Зеландія, Австрія, Швейцарія і Венесуела - більше 50 \%). Китай є найбільшим виробником електроенергії на гідроелектростанціях (721 млн. кВт*год. в 2010 р.), а використовує лише 17 \% від потенційних можливостей.

Особливості роботи гідротехнічних споруд (далі - ГТС) полягають в тому, що вони постійно контактують 3 водою, яка знаходиться у спокої або русі, може бути солена або прісна і чинить на споруди механічні, фізико-хімічні та біологічні дії, а також в унікальності гідрологічних, топографічних, 


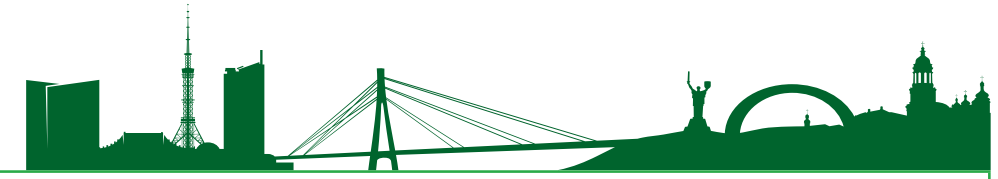

інженерно-геологічних та інших природних умов, в яких будуються гідротехнічні споруди, а також в їх масивності і значних розмірах, що необхідно враховувати при їх проектуванні.

Гідротехнічні споруди належать до інженерних споруд, які мають підвищену економічну, екологічну та соціальну значимість. Тому питанням їх надійності і безпеки у всьому світі приділяється значна увага. У водогосподарському комплексі України існує біля 50 типів лише постійних гідротехнічних споруд, найнебезпечнішими з яких є греблі, що входять до складу напірного фронту, та становлять найвищу гідродинамічну небезпеку техногенного характеру для населення та територій, особливо класу наслідків (відповідальності) СС3 та СС2-1. Аварії на цих греблях мають багатофакторний вплив на природне середовище та господарську діяльність людини. В Україні такі греблі розглядаються як потенційно небезпечні об'єкти, надійність і безпека яких повинні бути забезпечені в період будівництва, експлуатації, а також при консервації та ліквідації цих споруд і тому вони вимагають підвищеної уваги. Багато гребель в світі експлуатуються десятки, сотні і навіть тисячі років і зарекомендували себе в цілому стійкими та надійними спорудами. Наприклад, в Англії $50 \%$ гребель побудовано більше 80 років тому, в Іспанії 10 гребель функціонують більше 1000 років. У верхів'ях Рейну досі експлуатується найстаріша в Европі ГЕС Рейнфельден, побудована в 1880 році.

В світі побудовано 45000 гребель висотою понад 15 м або з водосховищами об'ємом більше 1 млн. м³. На основі аналізу статистики аварій, пошкоджень та руйнувань гребель, що мали місце в світовій практиці гідротехнічного будівництва, Міжнародна комісія з великих гребель (далі - ICOLD) свідчить про неможливість досягнення греблями абсолютної надійності та безпеки. Більшість гребель побудовано сучасними методами, на основі сучасних проектів. Однак світова статистика і події останніх років свідчать про можливість їх пошкоджень і руйнувань (рисунок 1).

Одна із останніх значних аварій на греблях відбулася 25 січня 2019 року в Брумадінью (Бразилія), коли сталось катастрофічне пошкодження хвостосховища на залізодобувній шахті (рисунок 2). Станом на 26 січня 2019 року, підтверджено 40 загиблих і щонайменше 300 зниклих безвісти, з яких 200 були працівниками греблі і 100 були жителями сусідніх сіл і будівель.

Аварія на греблі США біля м. Оровілл у Каліфонії відбулася у липні 2017 році. Щоб уникнути значних руйнувань витрату води на водоскиді було збільшено до $2800 \mathrm{~m}^{3}$ на хвилину (рисунок 3).

Аналіз статистики аварій та пошкоджень гребель в світі, виконаний ICOLD, дозволив визначити ймовірність їх виникнення: для гребель 3 грунтових матеріалів - (2,5-5,0) 10-4;

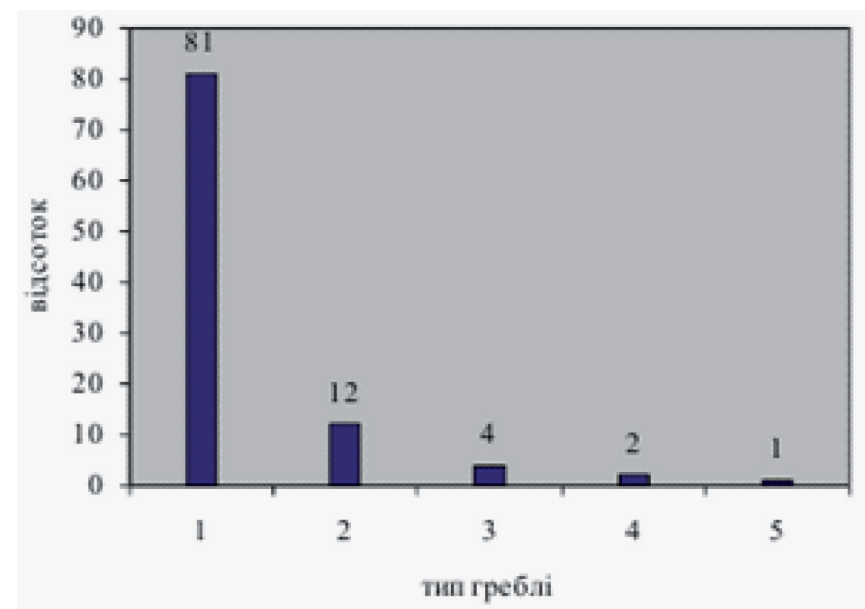

Рисунок 1 - Аварії і пошкодження гребель в залежності від типу і матеріалу тіла греблі: 1 - греблі iз грунтових матеріалів; 2 - бетонні гравітаційні греблі; 3 - бетонні контрфорсні греблі; 4 - бетонні аркові греблі; 5 - бетонні багатоаркові греблі

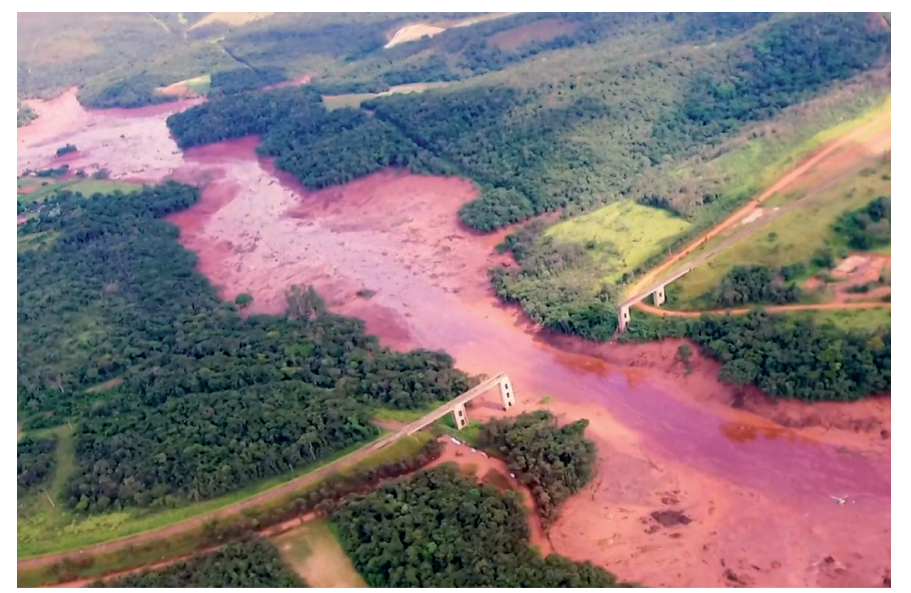

Рисунок 2 - Аварія на хвостосховищі в Брумадінью у 2019 році (Бразилія)

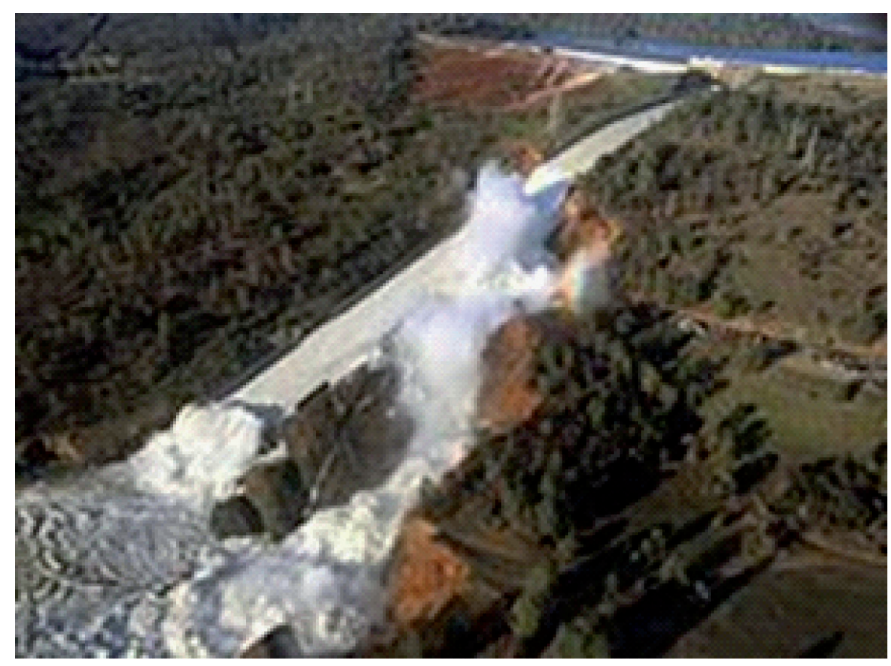

Рисунок 3 - Аварія на греблі СІІА біля м. Оровілл у Каліфонії (11.07.2017 р.) 


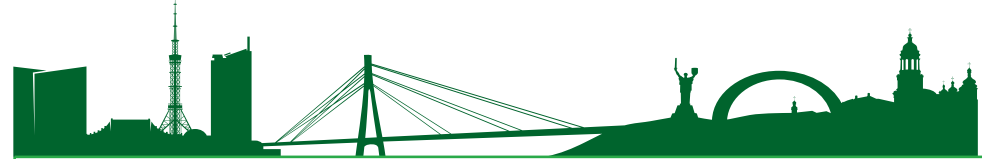

для бетонних гребель - (0,5-2,0) 10-4. Допустимі значення імовірностей виникнення аварій на напірних гідротехнічних спорудах в Україні становить 5,0 10-5 для СС3 та 5,0 10-4 - для СС2-1, що на порядок нижче ніж прийнятого у світовій практиці гідротехнічного будівництва [1]. За даними ICOLD після 40...50-річної експлуатації гребель імовірність аварій та пошкоджень на них суттєво зростає. Основними причинами аварій та пошкоджень грунтових гребель в світовій практиці, за даними ICOLD, визначено: розмив (руйнування) тіла греблі або іï берегових спряжень (примикань) при переливі води через гребінь греблі в наслідок екстремальних витрат води; недостатньої пропускної здатності водоскидних споруд, геодинамічні аварії в зоні водосховища; порушення стійкості або деформації, що перевищують гранично допустимі значення (ГДЗ) для споруди [2], основи або в зоні їх спряження (примикання); порушення фільтраційної міцності або надмірної втрати води в основі чи в тілі греблі або в зоні їх спряженні (примикання).

\section{METА РОБОТИ}

Розробка системного підходу до стану ГТС гідроенергетичних об'єктів України, які експлуатуються тривалий час, що дозволить підтримувати їх надійність і безпеку.

\section{МЕТОДИКА ДОСЛІДЖЕНЬ}

Аналіз сучасного стану нормативної бази i технічного стану найбільш важливих i відповідальних ГТС України, які знаходяться в тривалій експлуатації.

\section{ЗАГААЬНА ХАРАКТЕРИСТИКА ГІДРО- ЕНЕРГЕТИЧНИХ ОБ'СКТІВ УКРАЇНИ}

Важливу роль в об'єднаних енергетичних системах України відіграють ГЕС і ГАЕС. Основу гідроенергетики України складає Дніпровський каскад ГЕС, потужність якого становить 3920 МВт, Дністровський каскад ГЕС потужністю 744 МВт та діючи малі ГЕС, загальна потужність яких близько 100 МВт. При цьому ГЕС, як правило, покривають пікову частину графіку навантаження енергосистеми, а ГАЕС покривають провальну частину графіку навантаження і виконують функцію аварійного та навантажувального резервів. Саме ГЕС із крупними водосховищами комплексного призначення i їх каскади (Дніпровський та Дністровський) виконують задачі регулювання річкового витоку, утворюють водногосподарські комплекси. Це призводить до прискорення розвитку оточуючої інфраструктури й економічне зростання регіонів України. Дніпровський каскад ГЕС та ГАЕС. Серед всіх гідроенергетичних об'єктів найбільше значення має Дніпровський каскад ГЕС. Важко переоцінити його роль у забезпеченні надійної роботи об'єднаної енергетичної системи
України. Підсумковий виробіток електроенергії всіма гідроелектростанціями Дніпровського каскаду становить до $90 \%$ виробітку усіх ГЕС України. Водосховища Дніпровського каскаду забезпечують комунально-побутові, промислові і сільськогосподарські потреби більш ніж половини території України. Тому питання надійної i безпечної експлуатації гідровузлів Дніпровського каскаду, розробка і удосконалення методів оцінки їх надійності і безпеки являються актуальними.

До складу Дніпровського каскаду ГЕС входять шість гідроелектростанцій - Київська, Канівська, Кременчуцька, Середньодніпровська, Дніпровська та Каховська, які побудовані в період з 1932 р. по 1972 р., а також Київська ГАЕС [3]. План розташування гідроелектростанцій Дніпровського каскаду та загальний вид на Київську ГАЕС наведено на рисунку 4, а загальні види на Дніпровський каскад ГЕС - на рисунку 5.

Будівництво Дніпровської ГЕС-2 (закінчено в 1978 р.) дозволило значно збільшити потужність ГЕС і середньорічне вироблення електроенергії.

Будівництво гідроелектростанцій Дніпровського каскаду дозволило забезпечити вироблення екологічно чистої пікової електроенергії, що створює сприятливі умови роботи енергосистеми України. В даний час здійснюється реконструкція ГЕС Дніпровського каскаду, яка дозволить підвищити надійність і безпеку основних споруд ГЕС каскаду, а також підвищити енергетичні характеристики. В результаті реконструкції сумарна встановлена потужність ГЕС Дніпровського каскаду буде підвищена на 187 МВт, а середнє багаторічне вироблення цих станцій збільшиться на 347 ГВт.·год. Загальні дані про ГЕС та ГАЕС Дніпровського каскаду та дані про встановлену потужність і середньорічне вироблення електроенергії на цих ГЕС до і після реконструкції наведено в таблиці 1.

Інженерно-геологічні умови майданчиків розміщення гідровузлів Дніпровського каскаду ГЕС різні. Основні споруди Кременчуцької і Дніпровської ГЕС розташовано на скельних грунтах, а всіх інших електростанцій - на нескельних грунтах, які мають порівняно низькі міцнісні характеристики.

До складу гідровузлів Дніпровського каскаду ГЕС та ГАЕС входять ГТС різних типів: руслові залізобетонні будівлі ГЕС з агрегатами та монтажними майданчиками (у тому числі поєднані з паводковими водоскидами); водоприймач 3 підвідним каналом та напірні залізобетонні й металеві трубопроводи (Київска ГАЕС), водозливні і глухі бетонні греблі із стоянами; щитові стінки (Дніпровська ГEC); земляні греблі та дамби з кріпленням укосів та дренажними пристроями; підвідні та відвідні канали; судноплавні шлюзи різних типів; водозабірна споруда (Каховська ГЕС).

Дністровський каскад ГЕС та ГАЕС. План розташування ГЕС та ГАЕС Дністровського каскаду наведено на рисунку 6. 


\section{WII 1 Man}
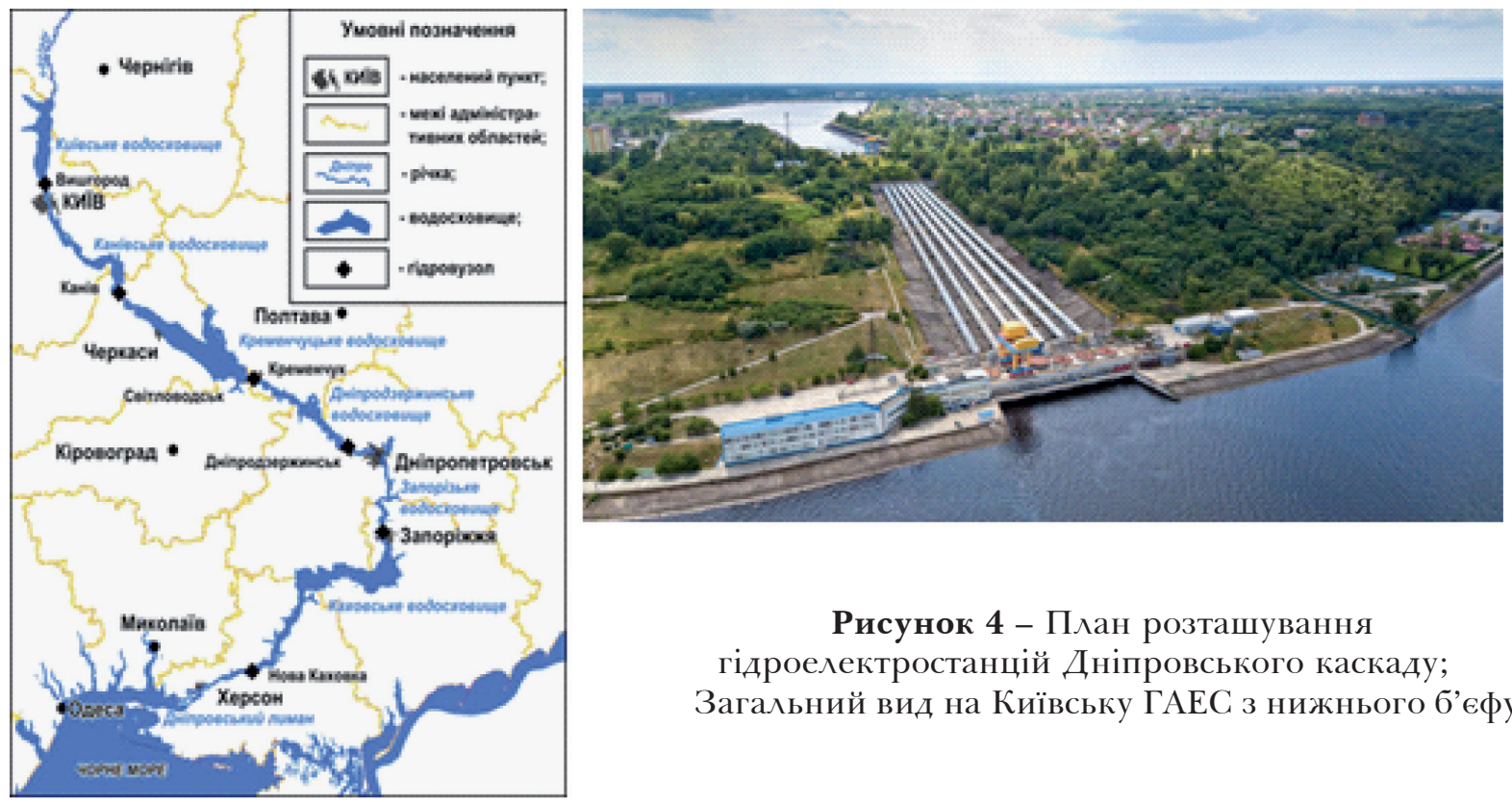

Рисунок 4 - План розташування

гідроелектростанцій Дніпровського каскаду;

Загальний вид на Київську ГАЕС з нижнього б’єфу
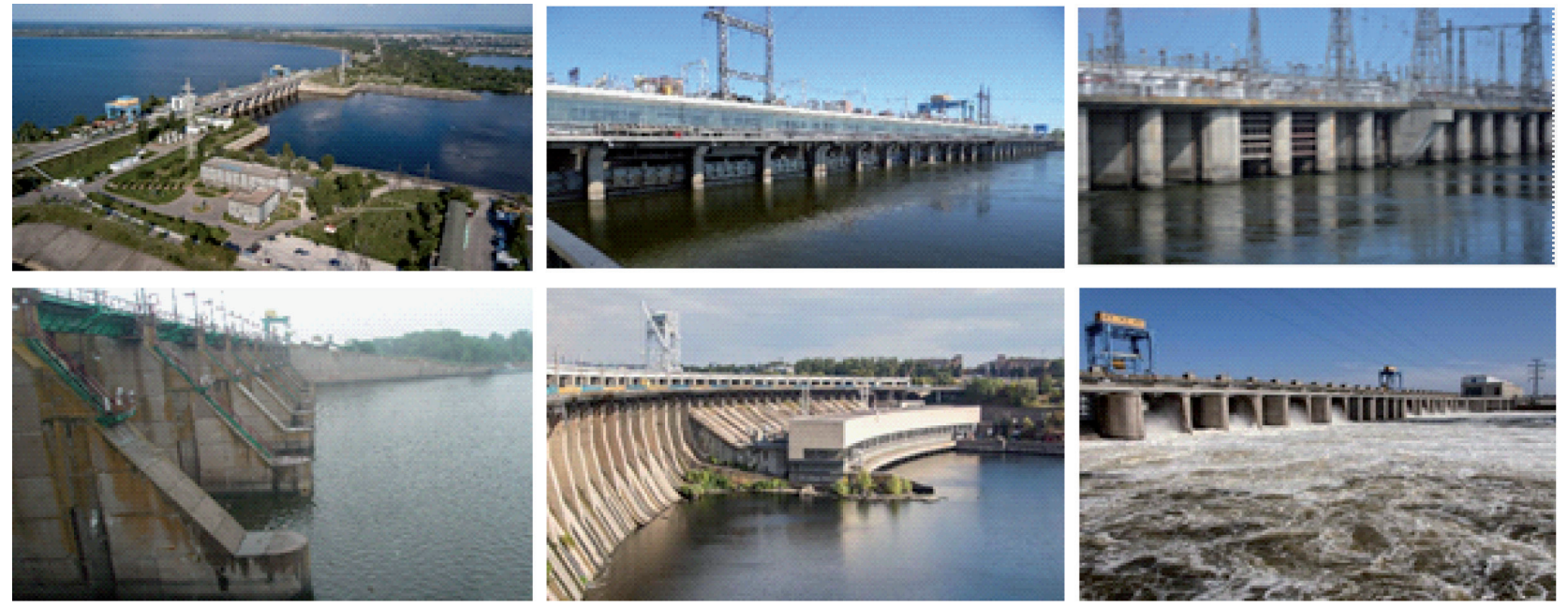

Рисунок 5 - Загальні види на ГЕС Дніпровського каскаду: Київська ГЕС, Канівська ГЕС, Кременьчуцька ГЕС, Середньодніпровська ГЕС, Дніпровська ГЕС, Каховська ГЕС
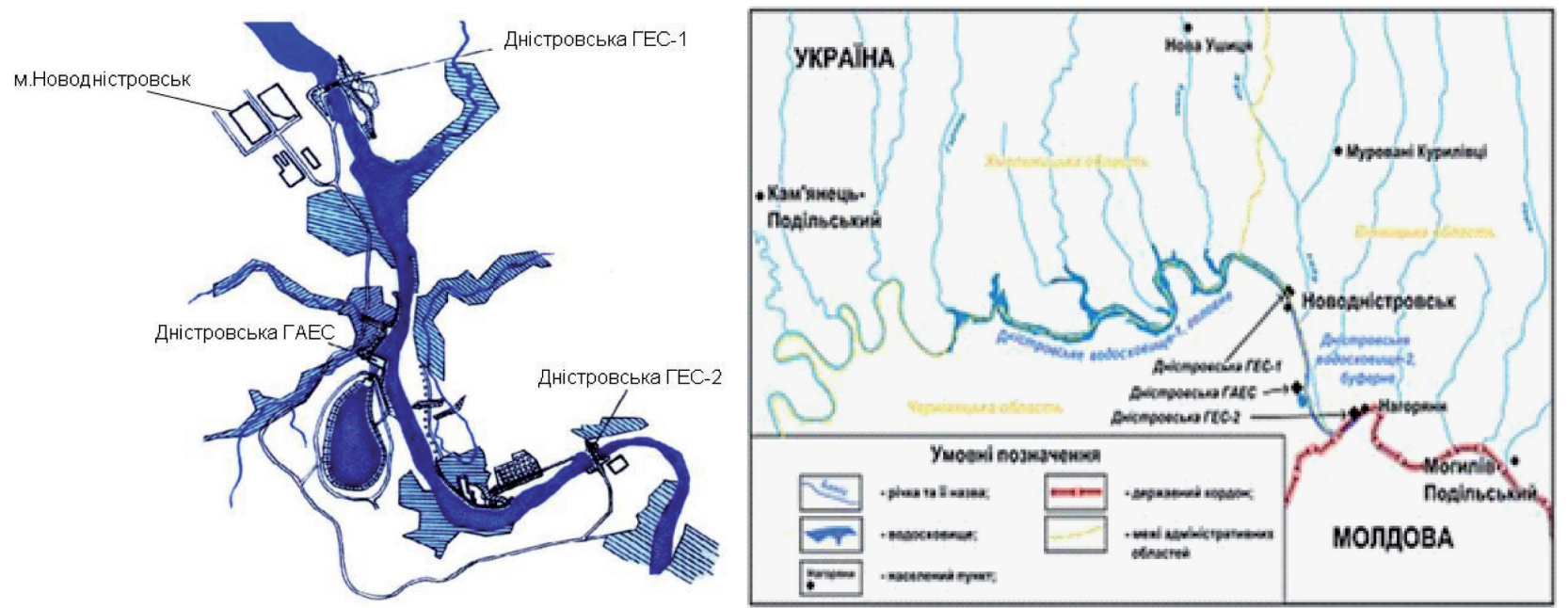

Рисунок 6 - Плани розташування гідроелектростанцій Дністровського каскаду 


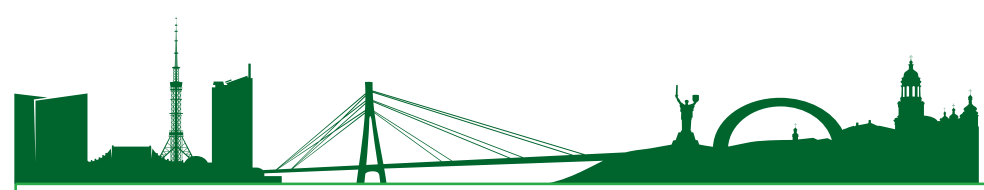

Таблиця 1 - Основні характеристики ГЕС та ГАЕС і водосховищ на Дніпрі

\begin{tabular}{|c|c|c|c|c|c|c|c|}
\hline \multirow[b]{2}{*}{ Характеристика } & \multicolumn{7}{|c|}{ ГЕС або ГАЕС } \\
\hline & $\begin{array}{l}\text { Київ- } \\
\text { ська } \\
\text { ГЕС }\end{array}$ & $\begin{array}{l}\text { Київська } \\
\text { ГАЕС }\end{array}$ & $\begin{array}{c}\text { Канів- } \\
\text { ська } \\
\text { ГЕС }\end{array}$ & $\begin{array}{c}\text { Кремен- } \\
\text { чуцька ГЕС }\end{array}$ & $\begin{array}{c}\text { Середньо- } \\
\text { дніпров- } \\
\text { ська ГЕС }\end{array}$ & $\begin{array}{c}\text { Дніпро- } \\
\text { вська ГЕС } \\
(\text { ГЕС-1+ГЕС-2) }\end{array}$ & $\begin{array}{c}\text { Кахов- } \\
\text { ська } \\
\text { ГЕС }\end{array}$ \\
\hline Тип ГЕС або ГАЕС & руслова & $\begin{array}{l}\text { дерева- } \\
\text { ційна }\end{array}$ & руслова & руслова & руслова & пригребельна & руслова \\
\hline $\begin{array}{l}\text { Рік введення в дію } \\
\text { агрегатів: } \\
\text { першого } \\
\text { останнього }\end{array}$ & $\begin{array}{l}1964 \\
1968\end{array}$ & $\begin{array}{l}1970 \\
1972\end{array}$ & $\begin{array}{l}1972 \\
1975\end{array}$ & $\begin{array}{l}1959 \\
1960\end{array}$ & $\begin{array}{l}1963 \\
1964\end{array}$ & $\begin{array}{l}1932 \\
1978\end{array}$ & $\begin{array}{l}1955 \\
1956\end{array}$ \\
\hline $\begin{array}{l}\text { Максимальний } \\
\text { напір на ГЕС, м }\end{array}$ & 11,8 & 65,0 & 13,5 & 13,6 & 15,26 & 38,2 & 16,5 \\
\hline $\begin{array}{l}\text { Максимальний скид } \\
\text { через турбіни, м³/с }\end{array}$ & 5600 & 413 & 7300 & 5400 & 4200 & 5000 & 2600 \\
\hline $\begin{array}{l}\text { Вид регулювання } \\
\text { стоку }\end{array}$ & сезонне & - & $\begin{array}{l}\text { добове і } \\
\text { тижневе }\end{array}$ & $\begin{array}{l}\text { річне } з \text { пе- } \\
\text { реходом на } \\
\text { багаторічне }\end{array}$ & $\begin{array}{l}\text { добове і } \\
\text { тижневе }\end{array}$ & $\begin{array}{l}\text { добове і } \\
\text { тижневе }\end{array}$ & річне \\
\hline $\begin{array}{l}\text { Рік введення в } \\
\text { експлуатацію } \\
\text { водосховища } \\
\text { Відмітки ФПР, м } \\
\text { НПР, м } \\
\text { ГМО, м }\end{array}$ & $\begin{array}{l}1965 \\
104,1 \\
103,0 \\
101,5\end{array}$ & $\begin{array}{c}1975 \\
- \\
174,2 \\
168,0\end{array}$ & $\begin{array}{l}1974 \\
92,7 \\
91,5 \\
91,0\end{array}$ & $\begin{array}{c}1961 \\
82,0 \\
81,0 \\
75,75\end{array}$ & $\begin{array}{l}1964 \\
66,0 \\
64.0 \\
63,0\end{array}$ & $\begin{array}{l}1932 \\
51,4 \\
51,4 \\
48,5\end{array}$ & $\begin{array}{l}1956 \\
18,0 \\
16,0 \\
12,7\end{array}$ \\
\hline $\begin{array}{l}\text { Площа дзеркала при } \\
\text { НПР, км² }\end{array}$ & 922 & 0,65 & 642 & 2250 & 567 & 400 & 2150 \\
\hline $\begin{array}{l}\text { Об’єм водосховища, } \\
\text { км³, повний } \\
\text { корисний }\end{array}$ & $\begin{array}{l}3,73 \\
1,17\end{array}$ & $\begin{array}{l}0,00479 \\
0,00379\end{array}$ & $\begin{array}{l}2,48 \\
0,28\end{array}$ & $\begin{array}{c}13,52 \\
8,97\end{array}$ & $\begin{array}{l}2,46 \\
0,53\end{array}$ & $\begin{array}{l}3,32 \\
0,85\end{array}$ & $\begin{array}{c}18,18 \\
6,78\end{array}$ \\
\hline $\begin{array}{l}\text { Середньобагато- } \\
\text { річний стік у створі } \\
\text { греблі, км }{ }^{3}\end{array}$ & 33,1 & - & 43,9 & 47,8 & 52,0 & 52,2 & 52,2 \\
\hline Кількість агрегатів & 20 & 6 & 24 & 12 & 8 & $9+8$ & 6 \\
\hline $\begin{array}{l}\text { Встановлена } \\
\text { потужність, МВт }\end{array}$ & $361 / 440$ & 235 & $444 / 528$ & $625 / 682,8$ & $352 / 387$ & $\begin{array}{c}585+876 / \\
648+900 \\
\end{array}$ & $300 / 335$ \\
\hline $\begin{array}{l}\text { Средне багаторічне } \\
\text { вироблення, млн. } \\
\text { кВтгод/ рік }\end{array}$ & $688 / 709$ & 140 & $916 / 945$ & $1495 / 1516$ & $1159 / 1232$ & $\begin{array}{r}1534+2209 / \\
1634+2271\end{array}$ & $\begin{array}{l}1254 / \\
1295\end{array}$ \\
\hline $\begin{array}{l}\text { Примітка. 1. В чисел } \\
2 . \text { В чисельнику с } \\
\text { реконструкції, кВт го } \\
\text { Нормальний підпірн }\end{array}$ & $\begin{array}{l}\text { ку стоїть в } \\
\text { с среднє } \\
\text { ік. } \\
\text { івень (НІ }\end{array}$ & $\begin{array}{l}\text { новлена по } \\
\text { аторічне в } \\
\text { Форсован }\end{array}$ & $\begin{array}{l}\text { жність до 1 } \\
\text { облення е } \\
\text { підпірний }\end{array}$ & $\begin{array}{l}\text { конструкції ГЕ } \\
\text { втроенергї̈ д } \\
\text { вень (ФПР) }\end{array}$ & $\begin{array}{l}\text { а в знаменнг } \\
\text { реконструкці }\end{array}$ & $\begin{array}{l}\text { - після реконстр } \\
\text { ЕС, а в знамен }\end{array}$ & $\begin{array}{l}\text { ції, МВт; } \\
\text { ку - після }\end{array}$ \\
\hline
\end{tabular}

Загальні види на ГЕС та ГАЕС Дністровського каскаду: Дністровська ГЕС; буферне водосховище Дністровської ГЕС (ГЕС-2); Дністровська ГАЕС наведено на рисунку 7.

Дані щодо водосховищ Дністровського каскаду ГЕС та ГАЕС наведені в таблиці 2.

Загальні дані про ГЕС та ГАЕС Дністровського каскаду наведено в таблиці 3.

Склад основних споруд гідровузлів Дністровського каскаду ГЕС та ГАЕС наведено в таблиці 4.

На даний час експлуатація ГТС, що входять до складу гідровузлів Дніпровського та
Дністровського каскадів ГЕС, здійснюється власником цих гідровузлів - ПрАТ «Укргідроенерго». Дотримання надійності та безпеки цих споруд здійснюється на основі оцінки їх технічного стану шляхом аналізу результатів візуальних обстежень i натурних інструментальних спостережень. На даний час на Дністровській ГЕС проводяться роботи з реконструкції протифільтраційного пристрою (ядра) земляної греблі для підвищення його протифільтраційних властивостей, що дозволить безпечно працювати ГЕС при відмітках води у водосховищі вище НПР.

Надійність та безпека гідротехнічних споруд 

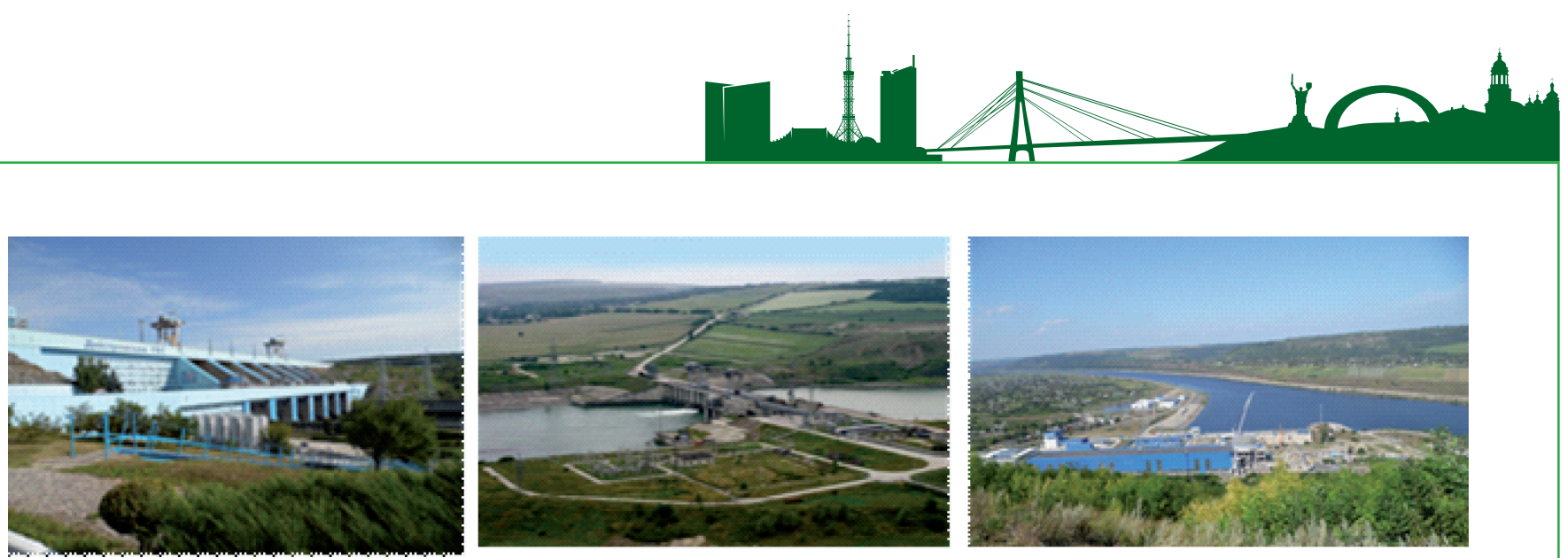

Рисунок 7 - Загальні види на ГЕС та ГАЕС Дністровського каскаду: Дністровська ГЕС; буферне водосховище Дністровської ГЕС (ГЕС-2); Дністровська ГАЕС

Таблиця 2 - Дані щодо водосховищ Дністровського каскаду ГЕС та ГАЕС

\begin{tabular}{|c|c|c|c|c|c|c|}
\hline \multirow[b]{2}{*}{ ГЕС, ГАЕС } & \multicolumn{3}{|c|}{ Розрахункові рівні води, м } & \multirow{2}{*}{$\begin{array}{l}\text { Корисний } \\
\text { об'єм (при } \\
\text { НПР), км }\end{array}$} & \multirow{2}{*}{$\begin{array}{c}\text { Повний } \\
\text { об'єм (при } \\
\text { ФПР), км }\end{array}$} & \multirow{2}{*}{$\begin{array}{c}\text { Площа } \\
\text { дзеркала } \\
\text { при } \\
\text { НПР, } \\
\text { км }^{2}\end{array}$} \\
\hline & (НПР) & (ФПР) & $(\mathrm{PMO})$ & & & \\
\hline Дністровська ГЕС & 121,00 & 125,00 & 102,00 & 2,000 & 3,000 & 142 \\
\hline $\begin{array}{l}\text { Буферний гідровузол } \\
\text { Дністровської ГЕС } \\
\text { (ГЕС-2) }\end{array}$ & 77,10 & 82,00 & 67,60 & 0,601 & 0,701 & 7,3 \\
\hline Дністровська ГАЕС & 229,50 & - & 215,50 & 0,327 & 0,414 & 2,61 \\
\hline
\end{tabular}

Таблиця 2 - Загальні дані про ГЕС та ГАЕС Дністровського каскаду

\begin{tabular}{|c|c|c|c|c|c|}
\hline ГЕС, ГАЕС & $\begin{array}{c}\text { Рік введення в } \\
\text { експлуатацію } \\
\text { першого/ } \\
\text { останнього } \\
\text { агрегату }\end{array}$ & Напір, м & $\begin{array}{c}\text { Середнє } \\
\text { багаторічне } \\
\text { вироблення, } \\
\text { млн кВт*год/ } \\
\text { рік }\end{array}$ & $\begin{array}{c}\text { Встановлена } \\
\text { потужність/ } \\
\text { кількість } \\
\text { агрегатів, } \\
\text { МВт }\end{array}$ & $\begin{array}{l}\text { Витрата води } \\
\quad \text { через } \\
\text { агрегати, } \text { м }^{3} / \mathrm{c}\end{array}$ \\
\hline $\begin{array}{l}\text { Дністровська } \\
\text { ГЕС }\end{array}$ & $1981 / 1983$ & 53 & 865 & $702 / 6$ & 1980 \\
\hline $\begin{array}{l}\text { Буферний } \\
\text { гідровузол } \\
\text { Дністровської } \\
\text { ГЕС (ГЕС-2) }\end{array}$ & $1999 / 2002$ & 13,1 & 105 & $40,8 / 3$ & 1280 \\
\hline $\begin{array}{l}\text { Дністровська } \\
\text { ГАЕС }\end{array}$ & $2009 / 2015$ & 157 & 2720 & $2268 / 2947 / 7$ & $\begin{array}{c}1890 \\
\text { (через сім } \\
\text { агрегатів) }\end{array}$ \\
\hline \multicolumn{6}{|c|}{$\begin{array}{l}\text { Примітки. 1. Для Дністровської ГАЕС встановлена загальна потужність наведена окремо для } \\
\text { генераторного та насосного режимів та вказана загальна кількість агрегатів (на даний час } \\
\text { введено в дію три агрегати першої черги). 2. Рік введення в експлуатацію останнього агрегату } \\
\text { для Дністровської ГАЕС наведено для 3-го агрегату. }\end{array}$} \\
\hline
\end{tabular}




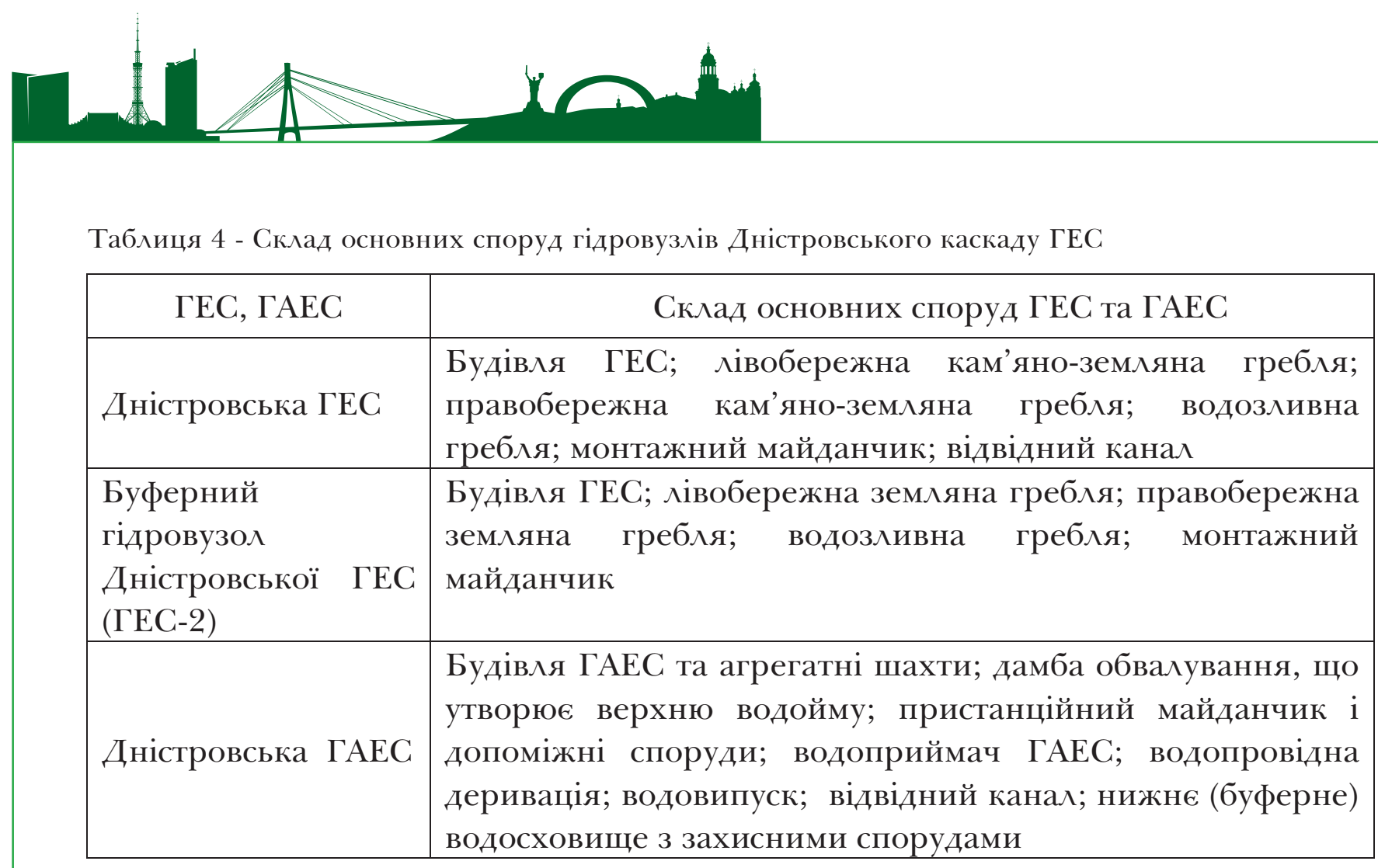

ГЕС забезпечуються на основі оцінки ї технічного стану шляхом аналізу та узагальнення даних натурних візуальних та інструментальних спостережень 3 впровадженням автоматизованої системи контролю (АСК) та системи моніторингу просторових зміщень споруд, проведенням комплексних досліджень поточного стану гідротехнічних споруд.

Слід зазначити, що, незважаючи на велику тривалість експлуатації, до теперішнього часу не було скільки-небудь значної аварії на ГТС гідровузлів Дніпровського та Дністровського каскадів ГЕС. Ця обставина дозволяє вважати достатніми на даний час надійність і безпеку цих споруд.

Галузева система нагляду за надійністю та безпекою гідротехнічних споруд і гідромеханічного обладнання електростанцій України, які експлуатуються чи будуються, основана на розробці і контролі виконання заходів, що підтримують надійність і безпеку гідротехнічних споруд відповідно до діючих правил і норм проектування, будівництва та експлуатації цих споруд (таблиця 5).

Енергетичне значення Дніпровського та Дністровського каскадів ГЕС і його висока екологічна та соціальна відповідальність, різноманіття природних умов, в яких зведені гідровузли каскаду, велика різноманітність конструкцій ГТС, що входять в гідровузли, а також значна тривалість експлуатації (від 47 до 87 років) дозволяють зробити висновок про те, що пріоритетним завданням для гідроенергетики України є розробка спеціальних заходів щодо забезпечення надійності цих споруд. При цьому Дніпровську ГЕС, що має найбільший термін експлуатації, слід розглядати як першочерговий об'єкт.

Практично у всіх розвинених країнах прийнято закон «Про безпеку гідротехнічних споруд», що пов'язано $з$ надзвичайно високою економічною, екологічною та соціальною відповідальністю ГТС. В Україні досі не прийнято відповідного закону, хоча розробка проекту закону ведеться вже досить тривалий час. Такий закон дозволив би забезпечити регулювання правових відносин, що виникають при здійсненні діяльності по дотриманню безпеки ГТС на всіх етапах їх життя, включаючи проектування, будівництво, експлуатацію, консервацію і ліквідацію. Закон міг би встановити обов'язки органів державної влади, власників та експлуатуючих організацій із дотримання безпеки гідротехнічних споруд. Тому видається необхідним організувати роботу щодо якнайшвидшого завершення розробки проекту закону та його прийняття.

В даний час відсутні нормативні документи і акти, які регламентують вимоги, виконання яких дає можливість безпечної експлуатації гідротехнічних споруд після закінчення призначеного терміну служби.

Існуючи критерії безпеки та відповідні їм стани споруд, наведені в [2], значною мірою застаріли. Тому необхідно розробити новий нормативний акт (ДБН), в якому будуть викладені основні вимоги щодо визначення критеріїв безпеки гідротехнічних споруд і на основі цього ДБН слід розробити відповідні галузеві будівельні норми (ГБН).

Для підвищення оперативності та достовірності контролю за станом безпеки та надійності гідротехнічних споруд Дніпровського та Дністровського каскадів ГЕС (напруженодеформованого стану бетону, осіданнями споруд та основи, п'єзометричними рівнями води та фільтраційними витратами в тілі, основі та в примиканнях до берегів земляних гребель тощо) вони оснащені автоматизованими системами контролю (далі - АСК). Рівень АСК визначається, в кожному окремому випадку, складом, об'ємом контрольно- 


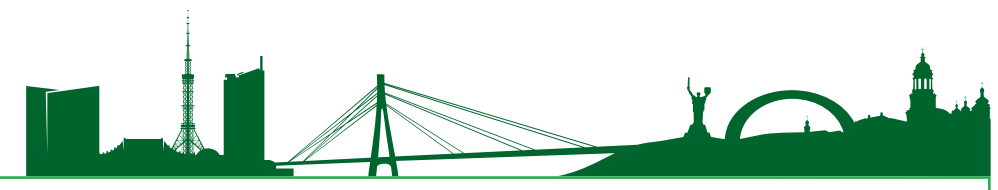

Таблиця 5 - Нормативно-правові акти, нормативні акти та нормативні документи щодо дотримання надійної експлуатації безпеки гідротехнічних споруд та безпеки людей

\begin{tabular}{|c|c|}
\hline Нормативні документи & $\begin{array}{c}\text { Закон і } \\
\text { нормативний акт } \\
\text { України щодо } \\
\text { дотримання } \\
\text { безпеки людей }\end{array}$ \\
\hline 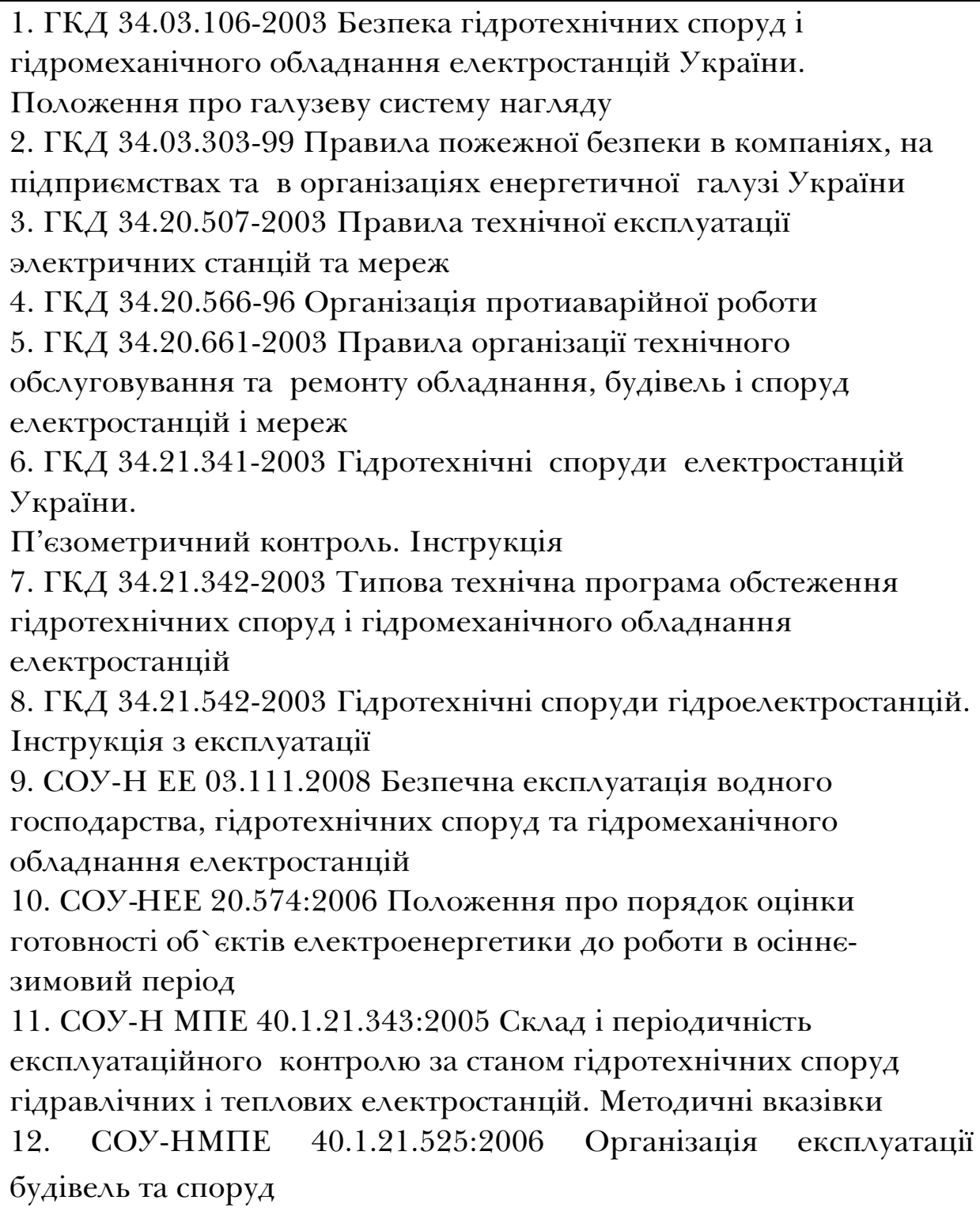 & $\begin{array}{l}\text { 1. Закон України } \\
\text { «ро охорону } \\
\text { праці» } \\
\text { 2. ДБН А.3.2-2-2009 } \\
\text { Охорона праці і } \\
\text { промислова } \\
\text { безпека у } \\
\text { будівництві. } \\
\text { Основні положення }\end{array}$ \\
\hline
\end{tabular}

вимірювальної апаратури (КІА), умовами їх експлуатації.

На науково-практичному семінарі «Зростаюча роль гідроенергетики в забезпеченні маневреності і балансування ОЕС України в умовах реалізації «Енергетичної стратегії України на період до 2035 р.», організованого ГС «Асоціація «Гідроенергетика України», що відбувся 05 листопада 2019 р. в м. Києві, були прийняті наступні рекомендації щодо оновлення нормативної бази України в області гідротехнічного будівництва при проектуванні, будівництві та експлуатації об' єктів гідроенергетики шляхом:

- прийняття Закону України «Про безпеку гідротехнічних споруд»;

- розроблення системного комплексу нормативних актів та документів (Технічного регламенту гідротехнічних споруд, державних та галузевих будівельних норм (ДБН та ГБН), державних стандартів України (ДСТУ), стандартів організацій України (СОУ) 3 урахуванням світового досвіду та напрацювань вітчизняних науко-дослідних інститутів;

- визначення джерел для залучення додат- 


\begin{tabular}{|c|c|c|c|}
\hline \multicolumn{4}{|c|}{$\begin{array}{l}\text { Таблиця } 6 \text { - Кількість документів, необхідних для оновлення } \\
\text { нормативної }\end{array}$} \\
\hline Ч.ч. & $\begin{array}{c}\text { Назва установ та організацій, } \\
\text { що затверджують і } \\
\text { приймають рішення }\end{array}$ & $\begin{array}{c}\text { Кількість } \\
\text { документів }\end{array}$ & Статус \\
\hline 1 & Верховна Рада України & 1 & $\begin{array}{c}\text { Закон } \\
\text { України }\end{array}$ \\
\hline 2 & Кабінет Міністрів України & 1 & $\begin{array}{l}\text { Технічний } \\
\text { регламент }\end{array}$ \\
\hline 3 & $\begin{array}{c}\text { Міністерство розвитку громад } \\
\text { та територій України }\end{array}$ & 8 & ДБН \\
\hline 4 & “Міненерговугілля” України & 3 & ГБН \\
\hline 5 & $\begin{array}{c}\text { Національний орган } \\
\text { стандартизації } \\
\end{array}$ & 6 & ДСТУ \\
\hline 6 & ПрАТ «Укргідроенерго» & 16 & COY \\
\hline
\end{tabular}

4. Необхідно розробити новий нормативний акт (ДБН), в якому будуть викладені основні вимоги щодо визначення критеріїв безпеки гідротехнічних споруд і на основі цього ДБН слід розробити відповідні галузеві будівельні норми (ГБН).

5. Необхідно розробити систему державних будівельних норм (ДБН), стандартів (ДСТУ) та галузевих будівельних норм (ГБН) Міністерства енергетики та вугільної промисловості України, які регламентують дії державних органів нагляду, власників і організацій, що їх експлуатують, щодо дотримання безпеки та надійності ГТС електростанцій, які перебувають у тривалій експлуатації, а також

кового фінансування, у тому числі й коштів міжнародних фінансових організацій.

Для реалізації рекомендацій цього науковопрактичного семінару пропонується розробити системний комплекс документів, що включає низку ДБН, ГБН, ДСТУ та СОУ, наведених в таблиці 6.

Ці документи стосуються надійності та безпеки гідротехнічних споруд, їх проектування, експлуатації, обстеження, критеріїв для контролю й оцінки технічного стану та реконструкції.

\section{ВИСНОВКИ.}

1. Враховуючи енергетичну значимість та значну екологічну та соціальну відповідальність ГТС Дніпровського та Дністровського каскадів ГЕС, а також тривалу експлуатацію (від 47 до 87 років), необхідно розробити спеціальні заходи щодо забезпечення їх надійності під час експлуатації. Дніпровську ГЕС, що найбільш довго експлуатується, слід розглядати як першочерговий об'єкт.

2. В даний час в Україні діє низка застарілих нормативних документів, що регламентують вимоги, щодо надійності і безпеки ГТС при їх проектуванні, будівництві та експлуатації. Тому необхідно найближчим часом розробити системний комплекс нормативних актів та документів (Технічний регламент гідротехнічних споруд, державні та галузеві будівельні норми (ДБН та ГБН), державні стандарти України (ДСТУ), стандарти організацій України (COУ) з урахуванням світового досвіду та напрацювань вітчизняних науко-дослідних інститутів для проектування, будівництва та експлуатації ГТС, забезпечення їх надійності.

3. Для правового регулювання діяльності із дотримання безпеки ГТС необхідно завершити розробку проекту і прийняти Закон України «Про безпеку гідротехнічних споруд». вимоги, щодо безпеки та надійності експлуатації ГТС електростанцій після закінчення призначеного терміну служби.

\section{БІБАІОГРАФІЧНИЙ СПИСОК}

1. Гідротехнічні споруди. Основні положення: ДБН В.2.4-3-2010. [Чинні від 2011-01-01]. Київ: ДП «Укрархбудінформ», 2010. 37 с.

2. Рекомендации по определению предельно допустимых значений показателей состояния и работы гидротехнических сооружений: П-836-85. Гидропроект. М.: Изд-во ин-та Гидропроект им. С.Я. Жука, 1985. 41 с.

3. Фаренюк Г. Г., Вайнберг О. І., Хлапук М. М., Шумінський В. Д. Надійність та безпека гідротехнічних споруд в умовах тривалої експлуатації. «Наука та будівництво». 2019. № 2 (20). C. 4-18.

\section{REFERENCES}

1. Hydraulic structures. Basic principles: DBN V.2.4-3-2010. (2010). [Effective from 2011-0101]. Kyiv: SE “Ukrarkhbudinform”.

2. Recommendations for determining the maximum allowable values of state and operation indicators of hydraulic structures. (1985). M.: Publishing House of the S. Ya.Zhuk Institute "Hydroprojekt".

3. Farenyuk, G., Vaynberg, O., Shuminskyi, V., Khlapuk, N. (2019). The reliability and safety of hydraulic engineering structures in conditions of long operation. "Science and construction", 2 (20), 4-18.

Стаття надійшла до редакції 01.09.2020 року 